УДК 343.1

DOI https://doi.org/10.51989/NUL.2021.6.35

\title{
СУДОВО-ОДОРОЛОГІЧНА ЕКСПЕРТИЗА ПІД ЧАС РОЗСЛІДУВАННЯ КРИМІНАЛЬНИХ ПРАВОПОРУШЕНЬ
}

\author{
Ящук Володимир Олегович, \\ здобувач наукового ступеня доктора філософії \\ кафедри криміналістики та судової медицини \\ Національної академії внутрішніх справ
}

\begin{abstract}
Виявлення, вилучення, дослідження, використання під час розслідування кримінальних правопорушень запахових слідів супроводжуються виникненням проблемних питань щодо доказового значення отриманих результатів, тому існує об'єктивна необхідність висвітлення окресленої проблематики. Метою статті є формування наукових засад судово-одорологічної експертизи та з'ясування практичних особливостей її проведення під час розслідування кримінальних правопорушень.
\end{abstract}

Судово-одорологічні експертизи проводяться відповідно до положень Конституції України, міжнародних договорів України, Кримінального процесуального кодексу України, Закону України «Про судову експертизу», інших нормативно-правових актів. Теоретичною основою судово-одорологічних експертиз $\epsilon$ наукові праці вчених, науково-методичні рекомендації. Судова експертиза запахових слідів вирішує ідентифікаційні та діагностичні завдання.

Акцентовано увагу на проблемній ситуації, що полягає у необхідності унормування проведення судово-одорологічної експертизи та реєстрації експертної методики судово-одорологічної експертизи, адже, відповідно до ч. 3 ст. 8 Закону України «Про судову експертизу», методики проведення судових експертиз підлягають атестації та державній реєстрації.

Нині відбувається якісно новий розвиток одорології як галузі криміналістичної техніки та наукового вчення. Напрацьовано нові положення щодо ефективного дослідження запахових слідів за сучасних умов, проведення судово-одорологічної експертизи відповідно до міжнародних стандартів та кращого світового досвіду.

Вітчизняна наука і практика потребують розроблення цієї проблематики задля формування наукових засад використання запахових слідів під час розслідування кримінальних правопорушень; розроблення стандартизованих правил виявлення, вилучення, дослідження та використання запахових слідів; формування методики судово-одорологічного дослідження у системі методик судово-експертних досліджень; створення системи одорологічних лабораторій, які повинні відповідати міжнародним стандартам, а також для використання висновків судово-одорологічних експертиз як джерела доказів у кримінальному провадженні.

Ключові слова: одорологія, криміналістика, судова експертиза, експертна методика, висновок експерта.

\section{Yashchuk Volodymyr. Forensic examination during the investigation of criminal offenses}

Detection, seizure, research, use of odorous traces in the investigation of criminal offenses is accompanied by the emergence of problematic questions about the probative value of the results, so there is an objective need to cover the outlined issues. The purpose of the article is to form the scientific basis of forensic odorological examination and to clarify the practical features of its conduct during the investigation of criminal offenses.

Forensic odorological examinations are conducted in accordance with the provisions of the Constitution of Ukraine, international treaties of Ukraine, the Criminal Procedure Code of Ukraine, the Law of Ukraine "On Forensic Examination", and other regulations. The theoretical basis of forensic odorological examinations are scientific works of scientists, scientific and methodological recommendations. Forensic examination of odor traces solves identification and diagnostic tasks.

Emphasis is placed on the problem situation, which is the need to standardize the forensic odorological examination and registration of expert methods of forensic odorological examination, because in accordance with Part 3 of Art. 8 of the Law of Ukraine "On forensic examination", methods of forensic examinations are subject to certification and state registration. 
Currently, there is a qualitatively new development of odorology as a branch of forensic science and science. New provisions have been developed for the effective study of odor traces under modern conditions, forensic odorological examination in accordance with international standards and best international experience.

Domestic science and practice require the development of these issues in order to: form a scientific basis for the use of odorous traces in the investigation of criminal offenses; development of standardized rules for detection, removal, examination and use of odor traces; formation of methods of forensic odorological research in the system of methods of forensic expert research; creation of a system of odorological laboratories that must meet international standards and to use the conclusions of forensic odorological examinations as a source of evidence in criminal proceedings.

Key words: odorology, criminology, forensic examination, expert methodology, expert opinion.

Постановка проблеми. Виявлення, вилучення, дослідження, використання під час розслідування кримінальних правопорушень запахових слідів супроводжуються виникненням проблемних питань та необхідністю їх вирішення. Зокрема, низка авторів наголошує на важливості використання запахових слідів під час доказування у кримінальному провадженні шляхом проведення судово-одорологічної експертизи [1], а деякі вчені не розглядають таку можливість, підкреслюючи орієнтуюче значення запахових слідів під час розслідування [2, с. 52].

Відповідно, потрібно дати відповідь на питання про те, чи може висновок судовоодорологічної експертизи використовуватися як джерело доказів у кримінальному провадженні; яких вимог слід дотримуватися під час збирання матеріалів для судово-одорологічної експертизи, ії̈ призначення та проведення.

Аналіз останніх досліджень і публікацій. Характеризуючи стан наукових досліджень щодо питань проведення судовоодорологічної експертизи, відзначаємо, що концептуальні засади проведення судових експертиз у кримінальному провадженні розкриті у праці Н.I. Клименко «Загальна теорія судової експертології» (Київ, 2018 рік) [3], а власне запахові сліди були предметом монографічного дослідження В.Д. Басая «Основи криміналістичної одорології» (Івано-Франківськ, 2003 рік) [4]. Однак такий вид експертного дослідження, як судово-одорологічне, залишається розкритим недостатHьO.

Метою статті $\epsilon$ формування наукових засад судово-одорологічної експертизи та з'ясування практичних особливостей її проведення під час розслідування кримінальних правопорушень.

Виклад основного матеріалу дослідження. Своєчасне виявлення та дослідження слідів кримінального правопорушення сприяє встановленню обставин і механізму його вчинення, а також особи, якій вони належать. Саме тому КПК України до засобів отримання відомостей про обставини кримінального правопорушення відносить експертизу (ст. 242), яка являє собою дослідження експертом на основі спеціальних знань матеріальних об'єктів, явищ і процесів, що містять інформацію про обставини кримінального правопорушення, щодо якого здійснюється кримінальне провадження [5, с. 62].

Відповідно до ст. 1 Закону України «Про судову експертизу», судова експертиза - це дослідження на основі спеціальних знань у галузі науки, техніки, мистецтва, ремесла тощо об'єктів, явищ і процесів задля надання висновку з питань, що $€$ або будуть предметом судового розгляду [6].

Організація проведення судової експертизи починається з прийняття слідчим рішення про необхідність ії призначення та складається з таких етапів: вивчення матеріалів кримінального провадження щодо встановлення наявності підстав для призначення експертизи та об'єктів; визначення виду експертизи; визначення наявності порівняльного матеріалу для проведення експертизи (за необхідності); вибір часу призначення експертизи; вибір експертного закладу; винесення процесуального рішення про призначення експертизи, направлення рішення та необхідних матеріалів до експертної установи [7, c. 22]. 
У рішенні про призначення експертизи слідчий зазначає такі дані: місце й дата винесення постанови; посада, звання та прізвище слідчого; номер Єдиного реєстру досудових розслідувань; обставини провадження, які мають значення для проведення експертизи; підстави для призначення експертизи; прізвище експерта або назва експертної установи, експертам якої доручається проведення експертизи; питання, які виносяться на вирішення експерту; перелік об'єктів, що підлягають дослідженню (у тому числі, порівняльних зразків та інших матеріалів, направлених експерту, або посилання на такі переліки, що містяться в матеріалах справи); інші дані, які мають значення для проведення експертизи.

Обов'язково перераховуються всі об'єкти, які направляються на експертне дослідження, із зазначенням точного найменування, кількості, міри ваги, інших індивідуальних ознак.

До експертної установи, окрім рішення про призначення експертизи, надаються об'єкти, зразки для порівняльного дослідження, матеріали кримінального провадження за клопотанням експерта (протоколи оглядів з додатками тощо).

Питання, що можуть бути поставлені під час проведення відповідного виду експертизи, залежать від об'єктів дослідження та наявного порівняльного матеріалу. До порівняльного матеріалу (зразків для дослідження) висуваються такі вимоги:

1) не може бути піддано сумніву їх походження від об'єктів, що перевіряються;

2) вони повинні відображати достатній обсяг їх властивостей;

3) зразки повинні бути придатними для зіставлення з ідентифікуючими об'єктами.

Проведення судово-одорологічної експертизи ґрунтується на принципі законності відповідно до положень Конституції України, міжнародних договорів України, Кримінального процесуального кодексу України, Закону України «Про судову експертизу», інших нормативно-правових актів.

Експертна служба МВС України має необхідне кадрове та матеріально-технічне забезпечення для проведення судово-одорологічних експертиз, нині їх ефективне проведення забезпечує досягнення цілей кримінального провадження. Зокрема, позитивних відгуків практиків заслуговує одорологічна лабораторія Вінницького науково-дослідного експертно-криміналістичного центру МВС України.

Теоретичною основою проведення судово-одорологічних експертиз $\epsilon$ науково-методичні рекомендації, розроблені фахівцями експертного підрозділу [8], та праці вітчизняних учених [9, с. 436-439].

Судова експертиза запахових слідів (судово-одорологічна експертиза) дає змогу вирішити такі питання.

1) Чи наявні на наданих предметах (або у вилучених пробах) запахові сліди людини?

2) Чи походять запахові сліди, наявні на наданих предметах (фрагментах одного предмету), від особи, що перевіряється?

3) Чи наявні запахові сліди цієї особи у вилучених слідах крові, на волоссі?

4) Чи залишені вони однією або декількома особами, що перевіряються?

5) Особою якої статі залишені ці запахові сліди? [8, с. 49-50].

Таким чином, судова експертиза запахових слідів (судово-одорологічна експертиза) дає змогу вирішити як ідентифікаційні, так і діагностичні завдання.

Експертиза запахових слідів не відповідає на питання про те, чи $є$ особистий запах цієї людини в пробах повітря з місць вилучення, через недостатність пахучих речовин, що характеризують людину, у пробах повітря, а також про приналежність поданих об'єктів конкретній особі. Ці питання перебувають поза компетенцією експертів, що лише установлюють факт перебування на об'єктах запахових слідів тієї чи іншої особи.

Особлива увага приділяється підготовці до проведення судово-одорологічної експертизи, а саме відбору порівняльних зразків.

Оптимальним джерелом індивідуального запаху суб'єкта $€$ його кров, зразки якої в нього відбираються фахівцем із відповідною освітою на серветку з декількох прошарків стерильної марлі таким чином, щоб утворилась пляма діаметром 3-4 см. Кров висушують за кімнатної температури без застосування нагрівальних приладів і потрапляння прямих сонячних променів, вміщують у паперовий пакет, який опечатують і надписують. 
Одночасно з дотриманням усіх процесуальних вимог у особи, що перевіряється, вилучається предмет натільної білизни (наприклад, футболка), яку вона носила на день вилучення. Цей об'єкт упаковується у декілька прошарків алюмінієвої фольги й папір. Зразки крові та предмет одягу направляються експертам для проведення дослідження.

Методичні рекомендації містять дані про «одержання порівняльних запахових зразків з оперативною метою» [8, с. 50]. Однак вважаємо за доцільне зауважити, що цей спосіб відібрання зразків для проведення судово-одорологічної експертизи не відповідає чинному кримінальному процесуальному законодавству нашої держави, тому не може вважатися допустимим.

Разом із наведеною інформацією слід зауважити, що нормативно-правова регламентація проведення судово-одорологічної експертизи має суттєві недоліки. Так, проведення судово-одорологічної експертизи не регламентується за змістом Інструкції про призначення та проведення судових експертиз та експертних досліджень, затвердженої Наказом Міністерства юстиції України від 8 жовтня 1998 року № 53/5 [10].

Водночас у Положенні про Експертнокваліфікаційну комісію МВС та порядок проведення атестації судових експертів Експертної служби МВС, затвердженим Наказом МВС України від 20 вересня 2020 року № 675, визначено такий вид судової експертизи, як біологічна, та експертну спеціальність 9.7 «Одорологічні дослідження» [11]. У Реєстрі атестованих судових експертів, що ведеться Міністерством юстиції України, зареєстровані судові експерти за експертною спеціальністю 9.7 «Одорологічні дослідження» [12].

Таким чином, можемо констатувати виникнення проблемної ситуації, яка пов'язана з необхідністю унормування проведення судово-одорологічної експертизи у кримінальному проваджені та реєстрації експертної методики судово-одорологічної експертизи у відповідному реєстрі.

Висловлена пропозиція покликана забезпечити виконання ч. 3 ст. 8 Закону України «Про судову експертизу»: «методики проведення судових експертиз (крім судово-медичних та судово-психіатрич- них) підлягають атестації та державній реєстрації в порядку, що визначається Кабінетом Міністрів України» [6].

Таким чином, ми впритул наблизилися до надзвичайно важливого й принципового питання, що було поставлено на початку наукової статті: «Чи можуть результати одорологічних досліджень мати доказове значення у кримінальному провадженні?».

Отже, на думку В.О. Гусєвої [1, с. 71-76] та О.І. Ізотова [13, с. 154-157], результати одорологічної експертизи ніяк не можуть бути менш достовірними, ніж інші докази, і вони повинні розглядатися в сукупності з іншими наявними доказами у провадженні. Заперечення ж противників достовірності цих результатів критики не витримує, оскільки практика судочинства, цей найправильніший критерій теоретичних викладок, має вже чимало прикладів, коли висновки одорологічної експертизи приймалися беззаперечно судами першої і другої інстанції навіть тоді, коли вони становили основу обвинувачення [14]. Так, вивчення судової практики засвідчило, що на підставі наданих доказів, а саме висновку судово-одорологічної експертизи, громадянин $X$. був визнаний винним у вчиненні злочинів, передбачених ч. 1 ст. 263 КК України та ч. 2 ст. 383 КК України [14].

Методика проведення судово-одорологічної експертизи затратна з точки зору кадрових, організаційних, матеріальнотехнічних ресурсів і має тривалий строк проведення. Трапляються випадки, коли, попри об'єктивну необхідність, відбувається затягування строків ії проведення, що перешкоджає встановленню обставин кримінального провадження.

Такі висновки можна отримати за результатами вивчення Ухвали слідчого судді Воловецького районного суду Закарпатської області у справі від 7 червня 2021 року № 936/522/21. Так, слідчий суддя розглянув у відкритому судовому засіданні клопотання слідчого у кримінальному провадженні № 12021078090000034 за ознаками кримінального правопорушення, передбаченого ч. 3 ст. 185 КК України, про продовження строку тримання під вартою громадянина А., який підозрюється у вчиненні кримінальних правопорушень, передбачених ч. 3 ст. 185 КК України. Наявність обґрунтованої підозри 
громадянина А. підтверджувалася зібраними у кримінальному провадженні доказами, а саме протоколами огляду місця події, допитами свідків, протоколом проведення слідчого експерименту, висновками судових експертиз. Однак на час подання клопотання залишилась не виконаною судово-одорологічна експертиза спеціалізованою експертною установою (Вінницьким НДЕКЦ МВС України), а слідчий суддя, враховуючи ії велике значення для кримінального провадження, а також обґрунтування слідчого, продовжив клопотання про продовження строку досудового розслідування та тримання під вартою [15].

Висновки. Таким чином, сьогодні ми можемо констатувати якісно новий розвиток криміналістичної одорології як галузі криміналістичної техніки та наукового вчення. Вченими напрацьовано низку якісно нових положень щодо ефективного дослідження запахових слідів за сучасних умов, проведення судово-одорологічної експертизи відповідно до між- народних стандартів та кращого світового досвіду. Однак низка питань потребує невідкладного вирішення, зокрема вдосконалення нормативно-правового регулювання проведення судово-одорологічної експертизи, розроблення експертної методики судово-одорологічної експертизи.

Вітчизняна наука й практика потребують розроблення зазначеної проблематики задля формування наукових засад використання запахових слідів під час розслідування кримінальних правопорушень; розроблення стандартизованих правил виявлення, вилучення, дослідження та використання запахових слідів; формування методики судово-одорологічного дослідження у системі методик судово-експертних досліджень; створення системи одорологічних лабораторій, які повинні відповідати міжнародним стандартам, а також для використання висновків судово-одорологічних експертиз як джерела доказів у кримінальному провадженні.

\section{ЛITEPATУРA:}

1. Гусева В.О. Використання результатів одорологічного дослідження як доказів у кримінальному провадженні. Право і безпека. 2015. № 3 (58). С. 71-76.

2. Огляд місця події: виявлення та вилучення об'єктів біологічного походження : методичні рекомендації / упоряд. С.І. Перлін, С.О. Шевцов, Н.М. Косміна, В.В. Іонова. Харків : ФОП Чальцев О.В., 2009. 100 с.

3. Клименко Н.І. Загальна теорія судової експертології : монографія. Тернопіль : Крок, 2018. 262 c.

4. Басай В.Д. Основи криміналістичної одорології : дис. ... докт. юрид. наук : спец. 12.00.09. Івано-Франківськ, 2003. 652 с.

5. Лук'янчиков Є.Д., Лук'янчиков Б.Є. Отримання зразків для експертизи за чинним КПК України. Криміналістика і судова експертиза. 2017. Вип. 62. С. 61-68.

6. Про судову експертизу : Закон України від 25 лютого 1994 року № 4038-XII. Відомості Верховної Ради України. 1994. № 28. С. 232.

7. Рогальська В.В., Лускатов О.В., Терещенко А.І., Людвік В.Д., Пантелєєв К.М., Павлова Н.В., Бідняк Г.С. Примусовий відбір зразків у особи для проведення експертизи : методичні рекомендації для практичних підрозділів. Дніпро : ДДУВС МВС України, 2017. 36 с.

8. Можливості Експертної служби. Черкаси : Науково-дослідний експертно-криміналістичний центр при УМВС України у Черкаській області, 2015. 70 с.

9. Експертизи у судочинстві України : науково-практичний посібник / за ред. В.Г. Гончаренко, І.В. Гори. Київ : Юрінком Інтер, 2017. 504 с.

10. Інструкція про призначення та проведення судових експертиз та експертних досліджень : Наказ Міністерства юстиції України від 8 жовтня 1998 року № 53/5 / Верховна Рада України. URL: http://zakon4.rada.gov.ua/laws/show/z0705-98.

11. Положення про Експертно-кваліфікаційну комісію МВС та порядок проведення атестації судових експертів Експертної служби МВС, затв. Наказом МВС України від 20 вересня 2020 року № 675 / Верховна Рада України. URL: https://zakon.rada.gov.ua/laws/show/ z0022-21\#Text. 
12. Реєстр атестованих судових експертів / Міністерство юстиції України. URL: https:// rase.minjust.gov.ua/expert/8799.

13. Ізотов О.І. Проблеми достовірності результатів ольфакторних досліджень у криміналістичній одорології. Актуальні проблеми криміналістики та судової експертології : матеріали міжвідомчої науково-практичної конференції (Київ, 22 листопада 2018 року). Київ : Національна академія внутрішніх справ, 2018. С. 154-157.

14. Вирок апеляційного суду Житомирської області від 23 грудня 2011 року. Справа № 1/0690/4/11. Єдиний державний реєстр судових рішень. URL: http://reyestr.court.gov.ua/ Review/20386611.

15. Ухвала слідчого судді Воловецького районного суду Закарпатської області у Справі № 936/522/21 від 7 червня 2021 року у кримінальному провадженні № 12021078090000034. URL: https://youcontrol.com.ua/ru/catalog/court-document/97512443. 